\title{
1 High temporal resolution hydrometeorological data collected in the tropical 2 Cordillera Blanca, Peru (2004-2020)
}

3 Emilio I. Mateo ${ }^{1}$, Bryan G. Mark ${ }^{1}$, Robert Å. Hellström ${ }^{2}$, Michel Baraer ${ }^{3}$, Jeffrey M. McKenzie ${ }^{4}$,

4 Thomas Condom ${ }^{5}$, Alejo Cochachín Rapre ${ }^{6}$, Gilber Gonzales ${ }^{6}$, Joe Quijano Gómez ${ }^{6}$, Rolando

5 Cesai Crúz Encarnación ${ }^{6}$

$6{ }^{1}$ Department of Geography, Byrd Polar and Climate Research Center, The Ohio State University,

7 Columbus, $\mathrm{OH}, \mathrm{USA}$

$8 \quad{ }^{2}$ Department of Geography, Bridgewater State University, Bridgewater, MA, USA

9 '3épartement de génie de la construction, École de technologie supérieure, Montreal, QC,

10 Canada

$11 \quad{ }^{4}$ Department of Earth and Planetary Sciences, McGill University, Montreal, QC, Canada

${ }^{5}$ Université Grenoble Alpes, CNRS, IRD, Grenoble-INP, Institut des Géosciences de

13 l'Environnement (IGE, UMR 5001), Grenoble, France

$14{ }^{6}$ Peruvian National Water Authority, Division of Glaciers and Water Resources, Huaraz, Peru 
26 Abstract. This article provides a comprehensive hydrometeorological dataset collected over the past two decades throughout the Cordillera Blanca, Peru. The data recording sites, located in the upper portion of the Rio Santa valley, also known as the Callejon de Huaylas, span an elevation range of 3738 - $4750 \mathrm{~m}$ a.s.l. As many historical hydrological stations measuring daily discharge across the region became defunct after their installation in the 1950s, there was a need for new stations to be installed and an opportunity to increase the temporal resolution of the streamflow observations. Through inter-institutional collaboration the hydrometeorological network described in this paper was deployed with goals to evaluate how progressive glacier mass loss was impacting stream hydrology, and to better understand the local manifestation of climate change over diurnal to seasonal and interannual time scales. The four automatic weather stations supply detailed meteorological observations, and are situated in a variety of mountain landscapes, with one on a high-mountain pass, another next to a glacial lake, and two in glacially carved valleys. Four additional temperature and relative humidity loggers complement the weather stations within the Llanganuco valley by providing these data across an elevation gradient. The six streamflow gauges are located in tributaries to the Rio Santa and collect high temporal resolution runoff data. The datasets presented here are available freely from https://doi.org/10.4211/hs.059794371790407abd749576df8fd121 (Mateo et al., 2021). enable detailed research of atmospheric and hydrological processes in tropical high-mountain terrain. 
Glaciers and water resources in the Cordillera Blanca, Peru, have been under close observation for nearly a century. In the 1930s, an Austrian geographer from Universitat Innsbruck, Hans Kinzl, laid the groundwork for glaciological research in the region by surveying and mapping the glaciers and identifying other natural features in the mountainous landscape (Kaser and Osmaston, 2002). While the first systematic Peruvian effort to observe glacier tongue variations in the Cordillera Blanca was initiated in 1944 by Broggi (Petersen et al., 1969), glaciers as a source of security and water resources became the object of study in the subsequent decades. The Unidad de Glaciología e Hidrología (later Unidad de Glaciología y Recursos Hidricos (UGRH) of Electroperú S.A.) was initiated by the Corporación Peruana del Santa, a government company for energy development, and took on glacier and lake monitoring after many glacial lake outburst flooding (GLOF) events damaged communities downstream (Ames, 1998). GLOFs in 1941, 1945, and 1950 killed over 6000 people and destroyed a third of the Ancash district capital of Huaraz (Carey, 2010; Carey et al., 2012). Other glacier hazards have had detrimental impacts on the communities as well, including the 1970 avalanche, triggered by a massive earthquake, which killed approximately 6000 people and along with the debris flow it produced, covered the city of Yungay (Carey, 2010). Lliboutry, Morales and Schneider (1977) investigated two glaciers in the mountain range in relation to the danger they presented for flooding a downstream power plant. From the 1970s to the 1990s, a local Peruvian from Huaraz, Alcides Ames, provided many important contributions to the present knowledge of glaciers in the Cordillera Blanca while employed at UGRH, and after his retirement continued to dedicate much of his time to studying the glaciers and sharing his knowledge with other researchers (Ames et al., 1989; Hastenrath and Ames, 1995; Ames and Hastenrath, 1996; Ames, 1998; Kaser and Osmaston, 2002). In the 1980s, Georg Kaser, an Austrian geographer, began studying the Cordillera Blanca with a focus on the extent, causes, and possible consequences of the observed glacier retreat (Kaser and Osmaston, 2002). For many decades, much of the research in the region focused on developing better maps of the mountains and observing the marked glacier retreat in the tropics. Although the meteorological and hydrological stations installed by UGRH had been in place for nearly 40 years, it was not until the mid-1990s when studies began to assess water resources in the Cordillera Blanca, but with minimal focus on flooding and GLOFs (Kaser and Georges 1997; Mark and Seltzer, 2003).

The UGRH spent many years collecting an abundance of climatological, hydrological, and glaciological data, which was useful for future researchers, hydroelectric and mining companies, and other stakeholders throughout the Cordillera Blanca and its glaciers. Since the mid-1990s, most of the daily-resolution discharge data from the Rio Santa watershed has been cataloged and collected at a much reduced number of sites by private energy companies who took over after Electroperu was privatized. The rapid turnover of the energy companies holding the discharge observations makes it difficult to track down all available historical data. Also, many of the hydrological stations have become defunct since they were installed in the 1950s, 
96 creating a need for new stations to be installed for continuous monitoring of the region. A further benefit of installing a new hydrological monitoring network in the 2000s was to significantly increase the temporal resolution of the discharge observations.

Collaborating researchers from The Ohio State University, Bridgewater State University and McGill University initiated a network of embedded environmental sensors in 2005. The main goals of the instrument arrays were to evaluate how progressive glacier mass loss was impacting stream hydrology, and to better understand the local manifestation of climate change on the variability and controls of local weather phenomena over diurnal to seasonal and interannual time scales. In order to create a sustainable network for continuous, long term observation, this project has been maintained in close collaboration with Peruvian researchers and government agencies, as well as with other international scientists to leverage resources in maintaining instruments, in exchange for openly sharing data.

The instrumentation for the data collection we present in this work was installed and maintained under a collaborative work agreement ("convenio") formalized with the Peruvian government agency overseeing the office in Huaraz (Peruvian Institute of Natural Resources (INRENA) and the Autoridad Nacional del Agua (ANA)). This work agreement involved a secondary collaboration with other international researchers who shared in installing and calibrating the instrumentation. Specifically, Dr. Thomas Condom of the French Institut de Recherche pour le Developpement (IRD) joined the agreement to install and maintain a series of stream gauges logging water stage at 15 minute intervals. We also collaborated with the Austrian research team of Dr. Irme Juen and Professor Georg Kaser from the Universitat Innsbruck, Austria, who co-located a precipitation gauge with our weather station in Llanganuco. Further details about the instrumentation are provided below.

Inter-institutional collaboration in this fashion has provided an effective partnership to aid in maintaining the instrumentation over time, but also introduces challenges of logistical coordination and data continuity. Visitation as non-resident international scientists to the field sites has been feasible only one or two times annually. Thus, the Peruvians in our collaboration have incorporated our instruments within their routine monitoring network. This has permitted regular observations of stations and instruments to download data loggers, perform stream discharge measurement to build a rating curve, and undertake a limited range of repair work. However, limitations in local resources and manpower in Peru have often prevented recordings of stage observation and discharge measurement to constrain rating curves. Likewise, having multiple operators also increases some risk for data recovery errors. For instance, loggers that are improperly relaunched after data downloads can jeopardize subsequent acquisitions. Having more frequent site visits can allow for interventions, but also incurs increased risk of operator error. Furthermore, Peruvian domestic political changes have disrupted the operations by introducing different leadership, with altered operational priorities and resources, which directly or indirectly interrupt the continuity of trained personnel responsible for data recovery and 
preservation. Overcoming the many challenges of maintaining the instrumentation and constructing rating curves has required regular cross-cultural communication, multiple and annual visitation to the region.

Our collaborative observations have provided important new insights into how the hydroclimate of the region is changing on different scales. Updated discharge and climate observations in specific glacier catchments documented important shifts in seasonal supply of glacier storage to the Yanamarey catchment (Bury et al., 2011) as well as suggesting regional thresholds in glacier melt provision (Mark et al., 2010). The discharge constraints also provided important validation for a novel hydrochemical basin characterization method to quantify proportionate glacier melt and groundwater contributions to streamflow in tributaries of varying glacierized coverage (Baraer et al., 2009, 2015). Regionally, the gauge network provided the key constraint for a model of time-progressive hydrograph evaluation that verified significantly that the main catchment had already passed "peak water" in the wake of strong glacier recession underway for multiple decades (Baraer et al., 2012). Our embedded temperature and humidity loggers distributed over elevation and linked to weather stations in the Llanganuco valley have revealed novel diurnal to seasonal variations in lapse rates linked to catchment-specific valley wind dynamics validated with downscaled climate models (Hellstrom et al., 2017). These studies demonstrate the importance of collecting in situ hydrometeorological data and indicate the need for continued data collection in the high Andes (Condom et al., 2020).

In this paper, we document available data from the Cordillera Blanca area collected over the past 15 years. It is separated into (i) meteorological data recorded by permanently installed automatic temperature and relative humidity loggers (Lascars), or automatic weather stations, The data are stored in csv extension format on Consortium of Universities for the Advancement of Hydrologic Science, Inc. (CUAHSI) Hydroshare: https://doi.org/10.4211/hs.059794371790407abd749576df8fd121 (Mateo et al., 2021). The data collection consists of multiple time series of point observations from both meteorological and hydrological measurement sites. These high-temporal resolution data provide detailed insight into the complex hydro-meteorological system of the tropical Cordillera Blanca.

\section{Study Area - Cordillera Blanca}

The Rio Santa (Santa River) captures runoff from the western side of the glacierized Cordillera Blanca and the eastern side of the non-glacierized Cordillera Negra, encompassing a drainage area of $11636 \mathrm{~km}^{2}$ at the outlet to the Pacific Ocean. While the headwaters of the Rio Santa are found at Laguna Conococha at $4100 \mathrm{~m}$ above sea level (a.s.1.), the highest point in the basin (and in Peru) is the summit of Huascaran at $6768 \mathrm{~m}$ a.s.1.. The average slope of the entire drainage basin is $20.6^{\circ}$ and its average elevation is $3374 \mathrm{~m}$ a.s.l. calculated from a $3 \mathrm{~m}$ resolution DEM of the region. The Rio Santa flows over $300 \mathrm{~km}$ northwest from its origin at Laguna 
171 Conococha, an alpine lake at $4000 \mathrm{~m}$ a.s.l., to its outlet into the Pacific Ocean, near Chimbote.

172 The Callejon de Huaylas refers to the upper section of the Rio Santa, comprising approximately

$1734773 \mathrm{~km}^{2}$ located above the Cañon del Pato $50 \mathrm{MW}$ hydroelectric generation plant in Huallanca

174 (Figure 1). The Rio Santa basin is home to three other hydroelectric plants and provides water to

175 the expansive Chavimochic irrigation district near the coast (Mark and McKenzie, 2007). The

176 discharge on the Rio Santa has been carefully monitored since the Cañon del Pato dam began

177 operating in the 1950s, however, only one station near the dam remains active which is situated

178 slightly upstream at La Balsa (labeled as LBQ in Figure 1).

179 Figure 1.

180 Map of the Callejon de Huaylas showing the locations of the hydrological and meteorological

181 stations. (Base layers of the map originated from: ( Esri, () NASA, (C NGA, () USGS, (C) FAO,

182 (C) NOAA; all other layers were created and edited by authors of this article.) 


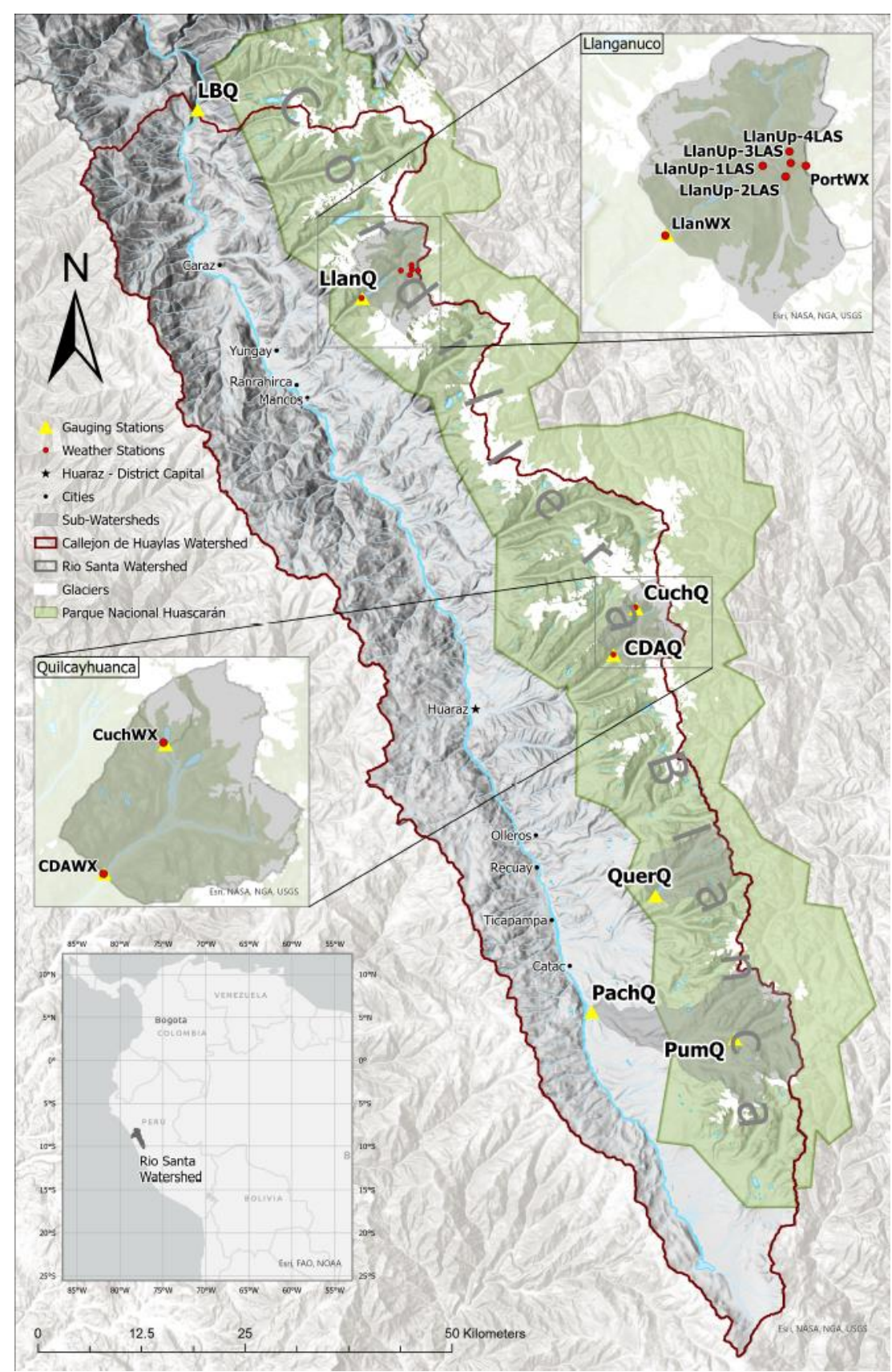

Rio Santa discharge experiences a strong seasonal contrast with the lowest discharge occurring between July and September, while peak discharge, nearly 20 times greater, typically occurs in March. Calculated from daily streamflow observations between 1954 and 2015, mean 
annual streamflow at La Balsa station on the Rio Santa, is $87 \mathrm{~m}^{3} \mathrm{~s}^{-1}$, while the average annual minimum discharge is $25 \mathrm{~m}^{3} \mathrm{~s}^{-1}$, and the average annual maximum discharge is $445 \mathrm{~m}^{3} \mathrm{~s}^{-1}$. The Callejon de Huaylas is approximately $10 \%$ covered in ice (RGI Consortium, 2017), has an average slope of $19^{\circ}$ and an average elevation of $4055 \mathrm{~m}$ a.s.1.. Glacial melt in the Rio Santa at La Balsa provides $10-20 \%$ of the total annual discharge and may exceed $40 \%$ in the dry season (Mark et al., 2005; Condom et al., 2012).

The climate of the Callejon de Huaylas is semi-arid and displays distinct precipitation seasonality, with the wet season between October and May being responsible for $80 \%$ of the 800-1200 mm/year of precipitation (Baraer et al., 2009), and the dry season lasting from June to September (Figure 2). As a localized example, the Llanganuco valley displays an average total of $8 \mathrm{~mm}$ during the dry season, and an average of total of $258 \mathrm{~mm}$ during the wet season months of December, January, and February, based on monthly totals from 1953 to 2010 (Hellstrom et al., 2017). Variations in river discharge are largely driven by seasonality of precipitation. Temperature remains nearly constant in the outer tropics, with the annual variation in temperature being smaller than diurnal variation (Kaser et al., 1990).

\section{Figure 2.}

A climograph of the Cordillera Blanca displaying the strong contrast in precipitation between wet and dry seasons, while maintaining a steady temperature throughout the entire year.

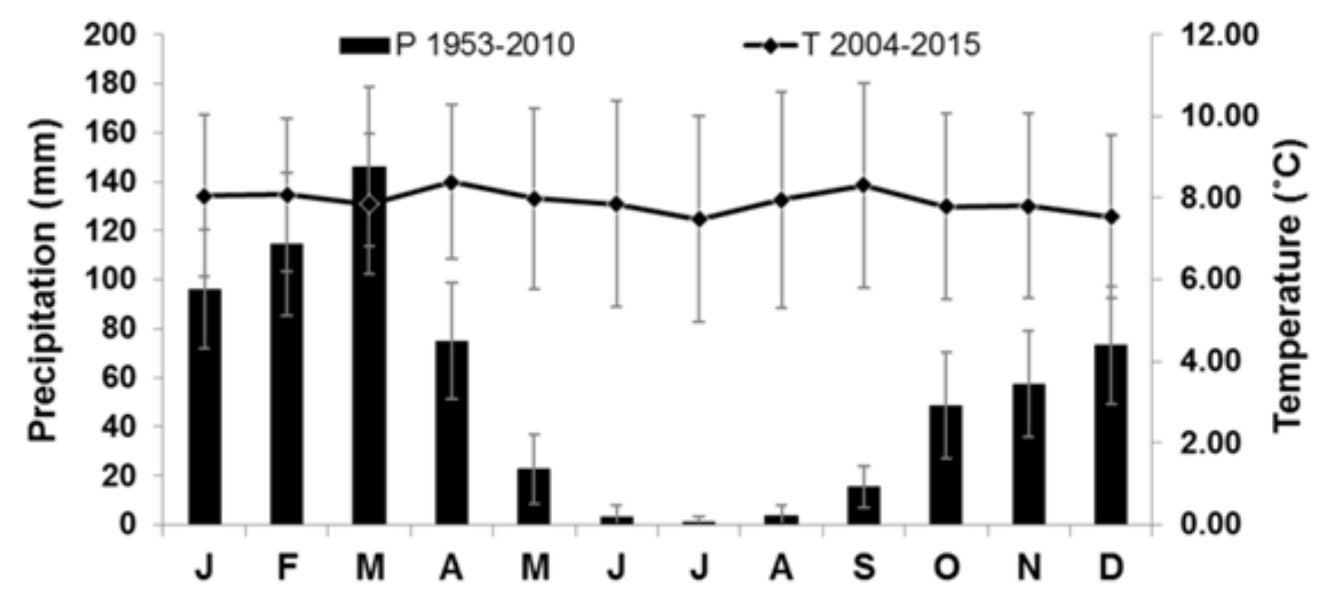

The geology in the Rio Santa basin is dictated by numerous tectonic and erosional processes because the basin is situated along the active detachment fault of the Cordillera Blanca (McNulty et al., 1998; Garver et al., 2005; Eddy et al., 2017). The highest peaks of the Cordillera Blanca are composed largely of a granodiorite batholith intruded into a metamorphic unit that includes hornfel, gneiss, and sulfide-rich lithologies, such as pyrite schist, phyllite, and pyritebearing quartzite (Giovanni et al., 2010; Eddy et al., 2017). Granodiorite is found predominantly in the northern portion of the range, while the southern portion of the range is made up of a 
214 variety of metasediments, including quartzites and carbonates (Garver et al., 2005). The main 215 valley of the Rio Santa watershed is covered by recent sediment deposits, including alluvium, 216 landslide deposits, and glacial-fluvial fill. The impact of past and present glacier extent in the 217 topography is visible in geomorphic features throughout the range, including steep walled U218 shaped valleys, moraines, and proglacial lakes (Eddy et al., 2017).

\section{The Data}

In the following section, the data collected from the Cordillera Blanca are presented in two collections. First, we provide a description of the meteorological stations and embedded sensor network of Lascar data loggers, and then we present the time series data from the stations. Second, we provide details of the setup and context of the discharge gauging station network, and conclude by presenting the time series of discharge data and general statistics from them.

\subsection{Meteorological Data}

The Servicio Nacional de Meteorología e Hidrología del Perú (SENAMHI) has operated a relatively dense national network of meteorological stations since 1964. Air temperature is provided as daily $T_{\max }$ and $T_{\min }$ (additionally measured at 07:00, 13:00 and 19:00 local time), and precipitation is measured once a day. In addition, the Universidad Nacional Santiago Antúnez de Mayolo (UNASAM) has maintained a network of what was originally 16 meteorological stations located at different elevations in the Cordillera Blanca (Ancash district) since 2012. Monthly totals of precipitation data for the Rio Santa watershed have been collected by Electroperú South America since 1953 although measurements were interrupted in 1994 with the privatization of the respective institutions when most of the stations were abandoned and quality control was an issue (Kaser et al., 2003). More recent installations of weather stations in the Cordillera Blanca have been mostly associated with short-lived research projects typically lasting less than three years (Hofer et al., 2010; Georges and Kaser, 2002). The hourly meteorological observations we describe below were collected primarily from instrumentation we installed in two subcatchments of the Rio Santa drainage basin, Llanganuco, and Quilcayhuanca.

The Llanganuco valley is situated on the western side of the Cordillera Blanca across a southwest $\left(\sim 240^{\circ}\right)$ to northeast $\left(\sim 60^{\circ}\right)$ axis with elevations ranging from $3400 \mathrm{~m}$ a.s.l. to $6746 \mathrm{~m}$ a.s.l. Llanganuco is one of most glacierized valleys in the mountain range at $30 \%$ glacier coverage, making it one of the most glacierized tropical valleys in the world. In the Llanganuco catchment, our group has installed multiple weather stations dating back to 2007, although only one remains active. This currently active station, labeled LlanWX, is located at 3835 m.a.s.l. near the lower of the two largest valley lakes (Table 1).

Table 1.

This table provides general information about each meteorological station and lascar data logger location within the embedded sensor network. 


$\begin{array}{lcc}\text { on }(\boldsymbol{m} \text { a.s.I.) } & \text { Period of Operation } & \text { Lascar Erro } A \\ 4642 & \text { 2013-Present } & \\ 3924 & \text { 2013-Present } & \\ 3835 & \text { 2007-Present } & \\ 4750 & \text { 2006-2015 } & \\ 3955 & 2006-2015 ; 2015-P r e s e n t & \\ 4122 & 2006-2014 ; 2015-P r e s e n t & \\ 4355 & 2006-2015 ; 2015-P r e s e n t & \\ 4561 & 2006-2015 ; 2018-P r e s e n t & \text { Y } \\ 4767 & 2007-2015 & \end{array}$

$\begin{array}{ll} & \text { Slope } \\ \text { ror Adjustment } & \\ -- & \\ \text { Yes } & \\ -- & \\ \text { No } & \\ \text { No } & \\ \text { No } & \\ \text { Yes } & \\ \text { Yes } & \end{array}$

\begin{tabular}{|cc|}
\hline 0 Angle $\left(^{\circ}\right)$ & Slope Aspect $\left(^{\circ}\right)$ \\
0 & NA \\
0 & NA \\
0 & NA \\
14 & NA \\
33 & 301 \\
31 & 259 \\
33 & 236 \\
9 & 225 \\
\end{tabular}

The embedded sensor network (ESN), as described by Hellström et al. (2010) and Hellström and Mark (2006), provides the in-situ meteorological data provided in the paper. In July 2004 the first automatic weather station (AWS), LlanWX, was installed near the lower lake in the Llanganuco valley to collect a continuous record of air temperature, wind speed, wind direction, relative humidity, solar irradiance, and soil temperature/moisture (Table 2). The AWS shown in Figure 3A is located in an open area on the valley floor and is surrounded by Polylepis trees. The site is protected in Huascaran National Park, and the location was previously used by the University of Innsbruck for precipitation measurements. The most significant wind obstructions are the steep bedrock walls of the valley toward the northwest and southeast which exceed 1000 meters above the valley floor. Northerly and southerly wind are occasionally recorded by LlanWX, and are likely caused by turbulence or lateral winds from the uneven heating of the valley walls. Winds flow parallel to the axis of the valley during approximately $92 \%$ of the recorded time and are not greatly obstructed by surface vegetation. The sensors for LlanWX were originally sourced from the Onset Computer Corporation and logged with an Onset $\mathrm{HOBO}{ }^{\circledR}$ data logger (http://www.onsetcomp.com) until 2014 these loggers were replaced with an Iridium ${ }^{\circledR}$ satellite Data Garrison logger (http://www.upwardinnovations.com). A 102 mm diameter radiation shield was used to reduce air temperature error caused by the sun except during the following years: 2007, 2011, 2012, 2013, and 2014; when a separate data logger was used as the primary source for air temperature and relative humidity observations. In 2013, our team upgraded the station by replacing the wind sensors with two new units from Onset and a new pyranometer from Apogee (http://www.apogeeinstruments.com/pyranometer) which exceeded the $1277 \mathrm{Wm}^{-2}$ maximum reading of the previous Onset sensors (Covert, 2016). The observations from LlanWX are largely continuous since 2005, with data gaps occurring occasionally between 2010 and 2014 .

Table 2.

This table details the variables, sensors, and their accuracy which are collected at the meteorological stations throughout the region. 


\begin{tabular}{|c|c|c|c|}
\hline Variable & Sensor & Accuracy & Unit \\
\hline Air temperature & $\begin{array}{l}\text { Onset HOBO S- } \\
\text { THB- } \\
\text { M002 Temperature } \\
\text { RH Smart Sensor }\end{array}$ & $\pm 0.2^{\circ} \mathrm{C}$ & ${ }^{\circ} \mathrm{C}$ \\
\hline Precipitation & $\begin{array}{l}\text { Onset HOBO S- } \\
\text { RGB-M002 } 0.2 \text { mm } \\
\text { Rainfall tipping } \\
\text { bucket Smart } \\
\text { Sensor }\end{array}$ & $\pm 0.2 \mathrm{~mm}$ & $\mathrm{~mm}$ \\
\hline Relative humidity & $\begin{array}{l}\text { Onset HOBO } \\
\text { Temperature RH } \\
\text { Smart Sensor: S- } \\
\text { THB-M002 }\end{array}$ & $\pm 2.5 \%$ & $\%$ \\
\hline Wind speed & $\begin{array}{l}\text { Onset HOBO S- } \\
\text { WSB-M003 Wind } \\
\text { Speed Smart } \\
\text { Sensor }\end{array}$ & $\pm 1.1 \mathrm{~m} / \mathrm{s}$ & $\mathrm{m} / \mathrm{s}$ \\
\hline Wind direction & $\begin{array}{l}\text { Onset HOBO S- } \\
\text { WDA-M003 Wind } \\
\text { Direction Smart } \\
\text { Sensor }\end{array}$ & $\pm 5^{\circ}$ & $\circ$ \\
\hline Incoming solar radiation & $\begin{array}{l}\text { Onset HOBO S- } \\
\text { LIN-M003 Solar } \\
\text { Radiation Smart } \\
\text { Sensor }\end{array}$ & $\pm 10 \mathrm{~W} / \mathrm{m}^{2}$ & $\mathrm{~W} / \mathrm{m}^{2}$ \\
\hline Atmospheric pressure & $\begin{array}{l}\text { Onset HOBO S- } \\
\text { BPB-CM50 Smart } \\
\text { Barometric } \\
\text { Pressure Sensor }\end{array}$ & $\pm 3.0 \mathrm{mb}$ & $\mathrm{mb}$ \\
\hline Soil temperature & $\begin{array}{l}\text { Onset HOBO S- } \\
\text { TMB-M002 12-bit } \\
\text { Temperature } \\
\text { Smart Sensor }\end{array}$ & $\pm 0.2^{\circ} \mathrm{C}$ & ${ }^{\circ} \mathrm{C}$ \\
\hline
\end{tabular}

A second AWS, situated at Portachuelo (referred to as PortWX in Figure 1), was installed in July 2006 on a high pass at the top of the Llanganuco valley (4742 $\mathrm{m}$ a.s.1.). The station was situated on a steep, rocky ridge between the Llanganuco valley and the Vaqueria valley. There were only wind obstructions to the north due to a steep rock wall within $10 \mathrm{~m}$ of the station location. The AWS at Portachuelo had the same sensors as its counterpart, LlanWX, however was lacking an air temperature and relative humidity sensor with a radiation shield until it was installed in July 2015. Prior to this upgrade, these variables were recorded each hour by a data logger part of the ESN discussed in the following section. The Portachuelo station was stolen in 2015 after recording data for nine years.

Figure 3. 
289

A) The typical setup for the HOBO automatic weather station, shown here is the LlanWX station near the lower lake in Llanganuco. Measurements include: air temperature, humidity, wind speed and direction, incoming solar radiation, rainfall, and soil temperature and soil moisture at $-10 \mathrm{~cm}$. Note also the Lascar in shield hanging from crossbar. B) Example of a Lascar data logger location shaded from sunlight and hidden from view in a polylepis tree. Photographs taken by R. Hellström (Covert, 2016).

A)

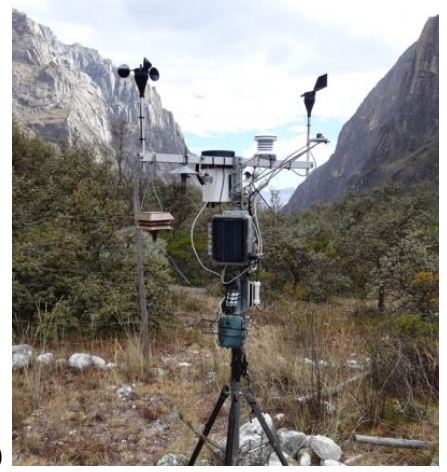

B)
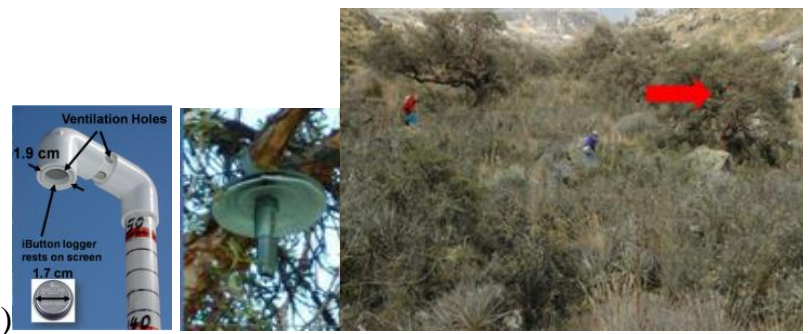

Smaller loggers measuring air temperature were installed in June 2005 to begin collecting near surface temperatures to calculate lapse rates. These data loggers were a series of 8 nickel sized iButton Thermochron ${ }^{\circledR}$ temperature loggers (Figure 3B). Hellström et al. (2010) demonstrated the effectiveness of using the Thermochron loggers for purposes of observing near surface lapse rates within the Llanganuco valley between the elevations 3470 and $4740 \mathrm{~m}$ a.s.l. (Covert, 2016). The ESN of iButtons was replaced in July 2006 with a more robust network of Lascar El-USB2 data loggers (www.lascarelectronics.com) which were setup to measure air temperature and relative humidity at one hour intervals. Figure 4 (from: Covert, 2016) provides photos for a visual landscape context for each Lascar logger. While using the weather observations provided, note that the LlanWX, LlanUp-4, and PortWX Lascar loggers are nearly entirely exposed to sunlight which led to higher than expected air temperatures and greater error from actual temperatures during the day (see section 4.1 for details). Each Lascar logger is attached to a custom-designed and locally crafted radiation shield made of a thin tin cone and two Styrofoam pieces in order to reduce error caused by direct sunlight, as shown in Figure 3B. This Lascar network is still recording hourly data.

Figure 4.

Photos A-F show the locations of all Lascar dataloggers which gathered data provided in this paper. Photographs taken by B. Mark and R. Hellström (Covert, 2016). 


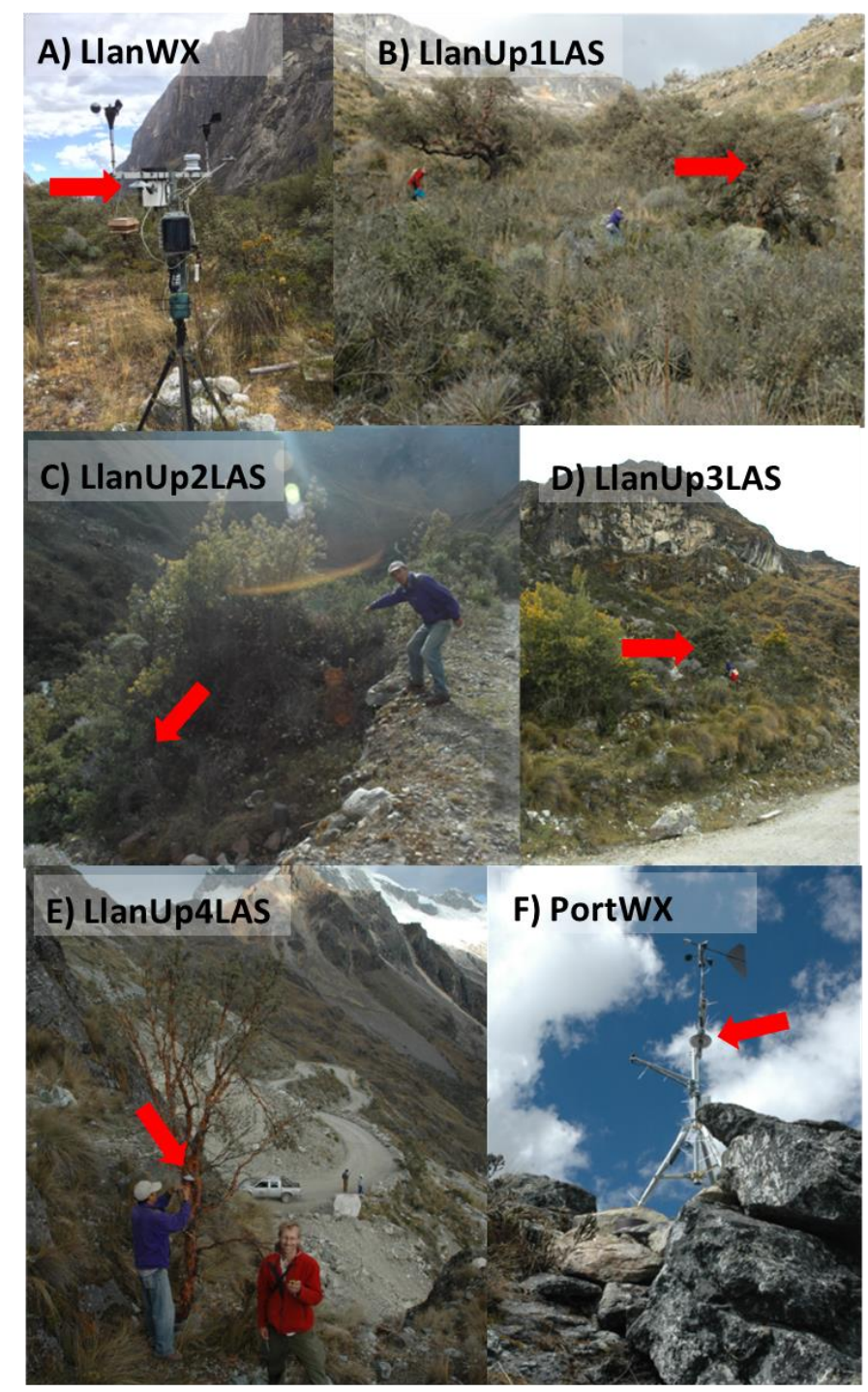

Quilcayhuanca contains two weather stations (Table 1) similar to the LlanWX station in 316 Llanganuco valley, the lower is located at $3924 \mathrm{~m}$ a.s.l. near an old river diversion station called 317 Casa de Agua (referred to as CDAWX in Figure 1), and the upper is located at $4642 \mathrm{~m}$ a.s.l.

318 slightly above an alpine lake, Cuchillacocha (referred to as CuchWX in Figure 1). The AWS at 319 Casa de Agua is still active since its installation in July 2013 and mostly continuous over this 320 duration. CDAWX station collects all of the same variables as LlanWX, which are described in Table 2. The Cuchillacocha AWS was also installed in July 2013 and is still presently active, and only has one data gap lasting longer than a month (from November 2016 - June 2017). 
The La Balsa gauge $\left(8.87^{\circ} \mathrm{S}, 77.82^{\circ} \mathrm{W}\right.$ at $1880 \mathrm{~m}$ a.s.l.) (Duke Energy, Orazul Energy, Inkia Energy) near the Cañon del Pato dam has a nearly complete record since 1954, acting as a long-term reference point for discharge on the Rio Santa at the base of the Callejon de Huaylas basin. Many other stream gauges and precipitation stations were put in place by the hydroelectric companies, however, due to the lack of maintenance these stations became unusable. In 2008, The Ohio State University, McGill University, IRD, and the Peruvian glaciology unit of ANA commenced a joint project to reinstitute a stream gauging network throughout the Cordillera Blanca (Baraer et al., 2012). Many of these redeployed stream gauges in sub-catchments of the Rio Santa are still in working condition and are continuing to be monitored.

The stream gauges comprise custom-designed and locally crafted steel stilling wells containing two Solinst leveloggers (Figure 5), with one measuring total pressure (water plus atmospheric), and the other measuring barometric pressure. The Model 3001 Solinst levelogger Edge has an accuracy of $\pm 0.05 \mathrm{kPa}$ and a resolution of $0.002 \%$ Full Scale (FS) for pressure and a temperature accuracy of $\pm 0.05^{\circ} \mathrm{C}$, and a temperature resolution of $0.003^{\circ} \mathrm{C}$ (www.solinst.com). Water level is continuously monitored at these gauges at a temporal resolution of 15-minutes by subtracting atmospheric pressure from the total pressure. Rating curves at all stations were established and verified by conducting discharge measurements using the velocity area method. Unavailable data is denoted by "NA" in the dataset. Linear interpolation of missing data was only calculated for missing periods of less than 1 hour, coinciding with the time the leveloggers were being downloaded in the field. Other than these short periods of interpolated data, the datasets provided consist of raw data.

Figure 5.

Figure 5 illustrates the design of the stilling wells used to collect total pressure (water + barometric) and barometric pressure.
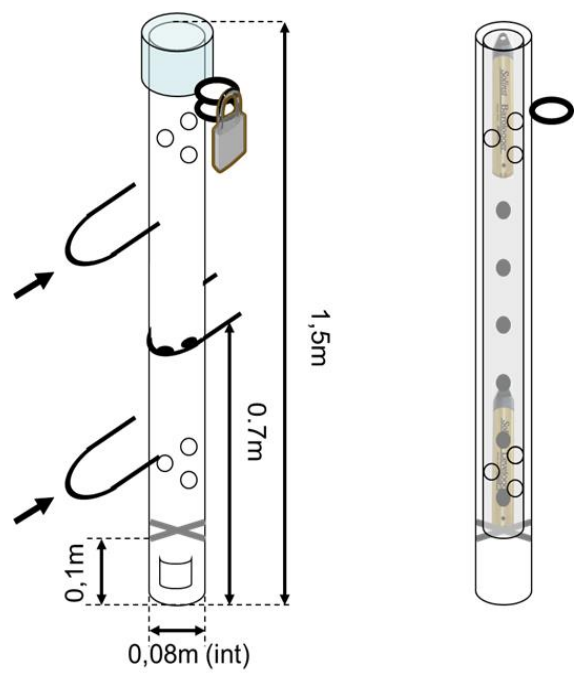
The stream gauges that were installed in 2008 and 2009 and which are continuing to

discharge are Casa de Agua, Cuchillacocha, Pachacoto, Llanganuco, and Querococha (Figure 1). The Pumapampa gauge went out of commission in 2016 but is also included in this dataset (Table 3). These stream gauges have variable lengths of record due to periods of missing data, but still provide valuable streamflow information in a region where stream records are limited. As shown in the map (Figure 1), two pairs of these stream gauges are located at different points along the same Rio Santa tributary in their respective sub-catchments: Pumapampa and Pachacoto in the Pachocoto valley; and Cuchillacocha and Casa de Agua in the Quilcayhuanca valley. All rating curves contain a minimum of eight point measurements throughout all times of the year. The following two subsections provide a brief overview and summary for each gauging station, organized by general location in the Cordillera Blanca, moving from the southern end of the mountain range to the northern. Note that all glacier coverage is calculated from RGI 6.0 (RGI Consortium, 2017).

Table 3.

This table provides geographical information about each of the hydrological gauging stations. Latitude and longitude are not provided for the security of the leveloggers. Note that all glacier coverage is calculated from RGI 6.0 (RGI Consortium, 2017).

\begin{tabular}{|l|cccc|}
\hline \multicolumn{1}{|c|}{ Station } & Elevation (m a.s.I.) & Period of Operation & Contributing Area (km²) & Percent basin covered in ice (\%) \\
\hline Cuchillacocha - CuchQ & 4631 & 2008-Present & 4.1 & 60.49 \\
Casa de Agua - CDAQ & 3948 & $2009-P r e s e n t$ & 66.9 & 24.78 \\
Pumapampa - PumQ & 4287 & $2008-2016$ & 58.1 & 8.33 \\
Pachacoto - PachQ & 3738 & $2008-P r e s e n t$ & 202.3 & 4.95 \\
Llanganuco - LlanQ & 3850 & 2008-Present & 86.9 & 30.32 \\
Querococha - QuerQ & 4005 & 2008-Present & 62.9 & 1.53 \\
\hline
\end{tabular}

\subsubsection{The southern Cordillera Blanca}

The Pumapampa catchment encompasses $58 \mathrm{~km}^{2}$ with about $8 \%$ being covered by glaciers (Table 3). Pumapampa gauge (referred to as PumQ in Figure 1) is located at $4287 \mathrm{~m}$ a.s.l., below Nevado Pastoruri at the southern end of the Cordillera Blanca. This stream gauge is situated in a channel through a low-lying meadow, where water overflowed its banks during high-volume flows causing inaccuracies in high discharge measurements. Most notably, a series of values in late-February indicated a peak discharge of $25 \mathrm{~m}^{3} \mathrm{~s}^{-1}$, well above extremes measured from the rating curve. It was determined that during this period the leveloggers were overrun by water and measurements became unreliable solely during this flooding event. Outside of this event, discharge at Pumapampa is consistently within the measured values on the rating curve. Mean annual streamflow (averaged from three years of data missing less than one-month during the entire year) at this stream gauge was $2.3 \mathrm{~m}^{3} \mathrm{~s}^{-1}$ and a specific discharge of $1248 \mathrm{~mm} \mathrm{a}^{-1}$. Mean streamflow during the dry season (May through September) in Pumapampa was $1 \mathrm{~m}^{3} \mathrm{~s}^{-1}$, while the mean streamflow during the wet season (October through April) was $2.9 \mathrm{~m}^{3} \mathrm{~s}^{-1}$. Highest mean monthly streamflow occurred in March 2014 with an average of $5.3 \mathrm{~m}^{3} \mathrm{~s}^{-1}$ (Figure 6). 
The Pachacoto gauge (referred to as PachQ in Figure 1) measures discharge $19 \mathrm{~km}$ downstream from Pumapampa, at 3738 m a.s.l., just above its confluence with the Rio Santa.

384 Streamflow at Pachacoto is significantly greater than Pumapampa as it is the drainage point for a 385 larger area of $202 \mathrm{~km}^{2}, 5 \%$ of which is covered by glaciers. The mean annual streamflow at 386 Pachacoto was $3.2 \mathrm{~m}^{3} \mathrm{~s}^{-1}$, averaged from the seven near-complete years of data, with a calculated 387 specific discharge of $499 \mathrm{~mm} \mathrm{a}^{-1}$. Dry season runoff accounted for approximately $20 \%$ of the 388 annual streamflow by volume, while the majority of the remaining wet season runoff occurred 389 during February and March.

Streamflow at another sub-catchment in the southern Cordillera Blanca is recorded at the Querococha gauge (referred to as QuerQ in Figure 1) at $4005 \mathrm{~m}$ a.s.l., located downstream of a large lake and a drainage area of $63 \mathrm{~km}^{2}$, including $1.5 \%$ of which is glacierized. This drainage collects from two watersheds, one of which is entirely deglaciated, and one which has a rapidly receding mass of ice. Using five years of complete data, the mean annual streamflow at this gauging station was calculated to be $1.4 \mathrm{~m}^{3} \mathrm{~s}^{-1}$ and the specific discharge was $702 \mathrm{~mm} \mathrm{a}^{-1}$. The streamflow from this gauge is somewhat regulated by the large lake residing $100 \mathrm{~m}$ upstream. This basin is home to many previous studies from our research group, and many other instruments throughout the basin are still consistently monitored by ANA.

399 Figure 6.

400 Figure 6 shows the monthly discharge at each of the gauging stations described in this study 401 calculated from complete months of data for each station. The strong seasonal pattern is clearly 402 visible at most of the stream gauges. 

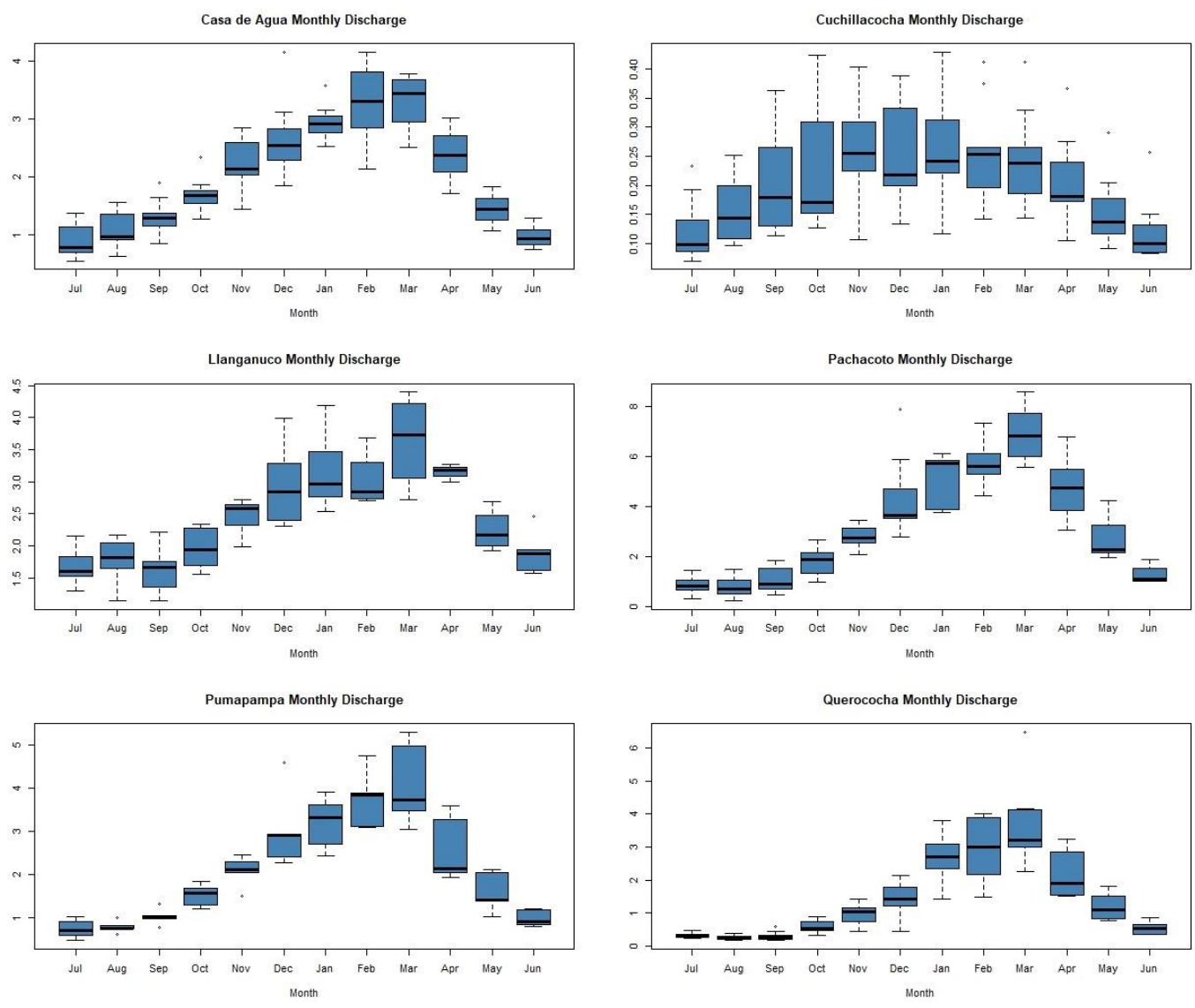

\subsubsection{The central and northern Cordillera Blanca}

405

406

407

408

409

410

411

412

413

414

415

416

417

Another catchment that contains two streamflow gauges is Quilcayhuanca, a valley directly above the region's most populous city, Huaraz. The higher elevation stream gauge is Cuchillacocha (referred to as CuchQ in Figure 1) which is situated at $4631 \mathrm{~m}$ a.s.l. and measures discharge below a high-alpine lake and two cirque glaciers encompassing a drainage area of 4 $\mathrm{km}^{2}$ (with $61 \%$ of the basin covered in ice). This station displays a noticeably different discharge pattern throughout the year than the lower gauging stations which collect greater runoff. Cuchillacocha discharge is not defined by a strong wet-dry season fluctuation, instead displaying more variability each month and rising to peak values much earlier in the wet season than other stream gauges. The average streamflow values at this location are also an order of magnitude lower than other gauging stations due to the small drainage area it collects from (Figure 6).

The stream gauge located at a lower elevation in the Quilcayhuanca valley is Casa de Agua (referred to as CDAQ in Figure 1) at $3948 \mathrm{~m}$ a.s.l. This gauging station is found near a channel cut in the stream, in a large meadow, where water was previously rerouted for 
418 agricultural purposes. This gauge collects drainage from an area of $67 \mathrm{~km}^{2}$ below the confluence

419 of two upper catchments, Cuchillacocha and Cayesh, well above the city of Huaraz ( $3100 \mathrm{~m}$

420 a.s.1.). From this drainage point in the watershed, the basin is approximately $25 \%$ glacierized.

421 The mean annual streamflow, calculated from six complete years of data at Casa de Agua, was 2 $\mathrm{m}^{3} \mathrm{~s}^{-1}$, with a specific discharge of $943 \mathrm{~mm} \mathrm{a}^{-1}$.

The last streamflow gauge still recording data, Llanganuco (referred to as LlanQ in Figure 1), is named after the valley it is located in and is positioned at $3850 \mathrm{~m}$ a.s.l., below two valley lakes and a catchment area of $87 \mathrm{~km}^{2}, 30 \%$ of which is currently glacierized. The mean annual streamflow, calculated from three complete years of data, was $2.3 \mathrm{~m}^{3} \mathrm{~s}^{-1}$, with a specific discharge of $835 \mathrm{~mm} \mathrm{a}^{-1}$. A stream gauge has been in commission at Llanganuco on and off for 68 years, beginning as a gauge for UGRH and hydroelectric companies and later, after the original station became defunct, a site for our new network of gauges.

\section{Data availability}

The datasets presented here are available freely from https://doi.org/10.4211/hs.059794371790407abd749576df8fd121 (Mateo et al., 2021). The hydrological and meteorological data from the Cordillera Blanca have been used in short segments in previous studies (Baraer et al., 2012; Baraer et al., 2015). Data availability varies from station to station depending on location of loggers and instrumental errors which caused periods of time to lapse without data being recorded. These datasets represent a majority of the streamflow and meteorological data collected by our research group over the past two decades collected at a high temporal resolution of 15-30 minutes. These include point discharge measurements and short-time periods of 1-minute temporal resolution meteorological measurements. The data provided here will be added to as future field seasons occur and the effort to provide hydrometeorological data to the scientific community will continue at all of the involved universities and institutions.

Figure 7.

Image A displays a Lascar data logger connected to its cone radiation shield. Two white Styrofoam plates beneath the cone insulate the sensor from radiative heating. Image B shows the radiation shields used on the AWS in comparison to the Lascar setup in image A. Image C shows polylepis trees which are used to hide and shade Lascars in order to obtain accurate temperature and relative humidity values. A comparison test between the Lascar setup and the AWS radiation shield with no shading yielded the expected errors shown in graph D. Positive values indicate that the Lascar reported a temperature higher than the AWS sensor. Photographs taken by R. Hellström (Covert, 2016). 

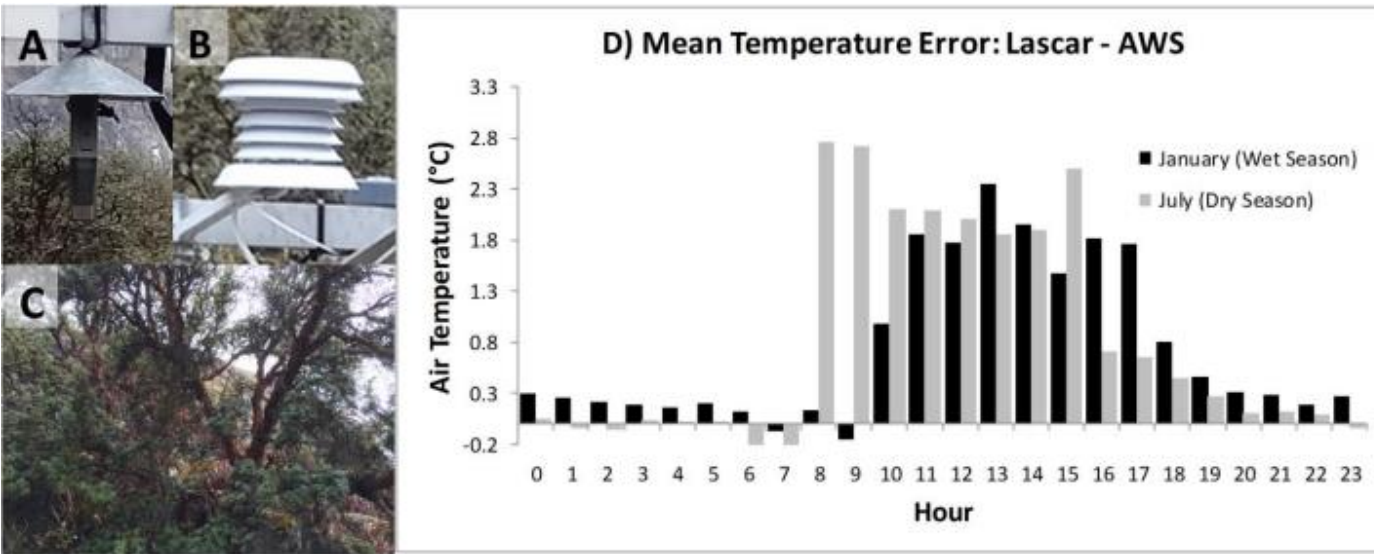

\subsection{Radiation Error for Lascar Temperature Loggers}

A year-long comparison between the Lascar setup (Figure 7) and LlanWX AWS indicated an expected error which was largely dependent on the time of day. Variability in temperature bias due to solar radiative heating is likely caused by changes in solar angle and cloud cover patterns, particularly during the dry season. It is well documented that temperature error rises on sunny days with calm wind and is reduced on windy and cloudy days regardless of the season, but is far more prominent during the dry season in the tropical Andes (Georges and Kaser, 2002). It is important to note that snow cover, which can create larger biases in temperature by reflected solar radiation, is minimal throughout the year at the locations of the Lascars in this study. Over an entire month, nightly error was within the $0.5{ }^{\circ} \mathrm{C}$ resolution of the Lascar sensor. The occasional occurrence of greater nighttime error could be caused by the sensor capturing longwave radiation emitted by the surface. Unlike the AWS radiation shield in which the temperature sensor is fully enclosed, the Lascar is exposed from below meaning it is able to capture longwave radiation at night. Further analysis will need to be done to verify this as the cause of the nocturnal error, though these errors are considered minimal for the uses of these datasets. The primary source of consistent instrumentation error for air temperature measurements is the heating of radiation shields from those locations exposed to direct sunlight, which required bias correction according to Figure 7. We bias-corrected for radiation error using comparison with the LlanWX shielded temperature and Lascar logger hanging next to it under the same exposure, including the LlanWX, LlanUp-4 LAS and PortWX station locations. Because solar radiation is the most significant source of error, corrections were only applied to daylight hours between 07:00 to 19:00 (Covert, 2016). During nighttime hours the error was within the sensor's output resolution and no corrections were applied. In addition to corrections for solar radiation heating, humidity and temperature records were assessed for accuracy and removed if there were unrealistic deviations from the previous 24-hour trend of conditions within the valley. Most of these deviations were due to an hour where sensors were downloaded and held by hand or in a pocket, although data (less than 1\%) were also removed if there was a 
481 concern with the integrity of the sensor. Due to theft or replacement of radiation shields, the four 482 Lascar loggers were renamed to LanUp-1A, 2A, 3A, and 4A in June 2015 and this is reflected in 483 the database. The most common reason for larger gaps in data was either loss of sensors due to 484 theft or inability to access sensors because of logistical reasons, such as poor weather windows 485 or human error in downloading or redeploying sensors.

\section{Conclusions}

487 The Cordillera Blanca in the tropical Andes of Peru is a unique, high mountain region 488 with a wealth of high resolution meteorological and hydrological time series observations 489 collected over the past two decades. The region has been the focus of glacier monitoring efforts 490 for nearly a century. While daily time series of meteorological and hydrological observations 491 have been recorded off and on for nearly 70 years, there was no generalized sub-daily data 492 monitoring until the early 2000s. Maintaining this network of instruments recording high493 temporal resolution data involves traveling to remote areas of the Cordillera Blanca, protecting 494 the instruments from the harsh weather conditions at high elevations, and concealing instruments 495 to prevent theft. There is also difficulty in developing long-term strategies because most funding 496 agencies are focused on short-term based projects and do not fund continuous monitoring and 497 maintenance of data collection networks. With climate change as an ongoing global situation, 498 and its harsh impacts at local levels, long-term monitoring of hydrometeorological variables will 499 become of utmost importance to understand the changes that are occurring.

500 The datasets collected and described in this paper support investigations into climate 501 evolution, water resource availability, and hydrological changes across the Cordillera Blanca in 502 the past twenty-years. These datasets will also provide valuable, easy-to-access observations for 503 local water resource managers. This paper provides an overview of the variables which have 504 been measured and what is being made available as of 2021. Future measurements recorded in 505 the field will be made available as they are collected, to further build on the available hydro506 meteorological database in the Cordillera Blanca.

\section{Author Contribution}

508 EM prepared the manuscript with contributions from co-authors. EM, RH and MB curated the 509 data in preparation for this article. BGM initiated research investigation and acquired initial 510 funding for data collection network. All authors assisted in gathering data and maintaining the 511 network of data collecting stations.

\section{Competing Interests}

513 The authors declare that they have no conflict of interest.

\section{Acknowledgements}


515 Funding for instrumentation, installation and field maintenance was provided by various

516 agencies and institutions associated with overlapping research projects and educational initiatives

517 through respective institutions. BGM acknowledges Ohio State University, National Science

518 Foundation (NSF \#0752175 with REU supplement; NSF \#1010384; NSF \#1316432), National

519 Geographic Society, NASA (New Investigator Program), and US Fulbright (Award \#4506).

520

521

522

523

524

525

526

527

528

529

530

531

532

533

534

535

536

537

538

539 
541 Ames, A., Munoz, G., Verastegui, J., Vigil, R., Zamora, M., and Zapata, M.: Glacier inventory of 542 Peru, Huaraz, Peru, 1989.

543 Ames, A. and Hastenrath S.: Mass balance and iceflow of the Uruashraju Glacier, Cordillera 544 Blanca. Peru, Zeitschrift fur Gletscherkunde und Glazialgeologie, 32 (2), 83-89, 1996.

545 Ames, A.: A documentation of glacier tongue variations and lake development in the Cordillera

546 Blanca, Peru, Zeitschrift fur Gletscherkunde und Glazialgeologie, 34 (1), 1-36, 1998.

547 Baraër, M., McKenzie, J. M., Mark, B. G., Bury, J. and Knox, S.: Characterizing contributions of 548 glacier melt and groundwater during the dry season in a poorly gauged catchment of the 549 Cordillera Blanca (Peru), Advances in Geosciences, 22, 41-49, 2009.

550 Baraër, M., Mark, B. G., McKenzie, J. M., Condom, T., Bury, J., Huh, K., Portocarrero, C., 551 Gomez, J., and Rathay, S.: Glacier recession and water resources in Peru's Cordillera Blanca, 552 Journal of Glaciology, 58, 134-150, doi: 10.3189/2012JoG11J186, 2012.

Baraër, M., McKenzie, J., Mark, B. G., Gordon, R., Bury, J., Condom, T., Gomez, J., Knox, S., 554 and Fortner, S. K.: Contribution of groundwater to the outflow from ungauged glacierized 555 catchments: a multi-site study in the tropical Cordillera Blanca, Peru, Hydrological Processes, 29 556 (11), 2561-2581, https://doi.org/10.1002/hyp.10386, 2015.

557 Bury, J. T., Mark, B. G., McKenzie, J. M., French, A., Baraër, M., Huh, K. I., and Gómez López, 558 R. J.: Glacier recession and human vulnerability in the Yanamarey watershed of the Cordillera 559 Blanca, Peru, Climate Change, 105 (12), 179-206, 2011.

560 Carey M.: In the Shadow of Melting Glaciers: Climate Change and Andean Society, Oxford 561 University Press, New York, 2010.

562 Carey, M., Huggel., C., Bury, J., Portocarrero, C., and Haeberli, W.: An integrated socio563 environmental framework for glacier hazard management and climate change adaptation: lessons 564 from Lake 513, Cordillera Blanca, Peru, Climate Change, 112, 733-767, 2012.

565 Condom, T., Escobar, M., Purkey, D., Pouget, J.C., Suarez, W., Ramos, C., Apaestegui, J., Tacsi, 566 A., and Gomez, J.: Simulating the implications of glaciers' retreat for water management: a case 567 study in the Rio Santa basin, Peru, Water International, 37, 442-459, 2012.

568 Condom, T., Martínez, R., Pabón, J.D., Costa, F., Pineda, L., Nieto, J.J., López, F., and Villacis, 569 M.: Climatological and Hydrological Observations for the South American Andes: In situ 570 Stations, Satellite, and Reanalysis Data Sets, Frontiers in Earth Science, 8, 92, 2020. 
571 Covert, J. M.: Observational Analysis of Inter-annual Boundary Layer Processes within the

572 Glaciated Llanganuco Valley, Peru. In BSU Honors Program Theses and Projects. Item 167.

573 Available at: http://vc.bridgew.edu/honors_proj/167 Copyright @ 2016 Jason Covert, 2016.

574 Eddy, A. M., Mark, B. G., Baraër, M., McKenzie, J. M., Fernández, A., Welch, S., and Fortner,

575 S.: Exploring patterns and controls on the hydrochemistry of proglacial streams in the Upper

576 Santa River, Peru, Revista de Glaciares y Ecosistemas de Montaña, 3, 41-57, 2017.

577 Garver, J. I., Reiners, P. W., Walker, L. J., Ramage, J. M., and Perry, S. E.: Implications for 578 timing of Andean uplift from thermal resetting of radiation damaged zircon in the Cordillera 579 Huayhuash, northern Peru, Journal of Geology, 113 (2), 117-138, 2015.

580 Georges, C. and Kaser, G.: Ventilated and unventilated air temperature measurements for 581 glacier-climate studies on a tropical high mountain site, Journal of Geophysical Research, 107 582 (D24), 4775, doi:10.1029/2002JD002503, 2002.

583 Giovanni, M. K., Horton, B. K., Garzione, C. N., McNulty, B., and Grove, M.: Extensional basin 584 evolution in the Cordillera Blanca, Peru: Stratigraphic and isotopic records of detachment 585 faulting and orogenic collapse in the Andean hinterland, Tectonics, 29 (6), TC6007, 586 doi:10.1029/2010TC002666, 2010.

587 Hastenrath, S. and Ames, A.: Recession of Yanamarey Glacier in Cordillera Blanca, Peru, during 588 the 20th century, J. Glaciology, 41, 191-196, https://doi.org/10.1029/94JD03108, 1995.

589 Hellström, R. Å., and Mark, B. G.: An embedded sensor network for measuring 590 hydrometeorological variability within a tropical alpine valley, Proceedings of the 63rd Eastern 591 Snow Conference, U. Delaware, Newark, DE, USA, 2006.

592 Hellström, R. Å., Higgins, A., Ferris, D., Mark, B. G., and Levia, D. F.: Impacts of complex 593 terrain on evapotranspiration within a tropical alpine valley in the Peruvian Andes, Proceedings 594 of the 67th Eastern Snow Conference, Jiminy Peak Mountain Resort, Hancock, MA, USA, 2010.

595 Hellström, R. Å., Fernandez, A., Mark, B. G., Covert, J. M., Cochachin, A., Gomez, J.:

596 Incorporating autonomous sensors and climate modeling to gain insight into seasonal

597 hydrometeorological processes within a tropical glacierized valley, Annals of the American 598 Association of Geographers, 107 (2), 260-273, https://doi.org/10.1080/24694452.2016.1232615, 5992017.

600 Hofer, M., Mölg, T., Marzeion, B., and Kaser, G.: Empirical-statistical downscaling of reanalysis 601 data to high-resolution air temperature and specific humidity above a glacier surface (Cordillera 602 Blanca, Peru), J. Geophysical Research, 115, D12120, doi:10.1029/2009JD012556, 2010. 
603 Juen, I., Kaser, G., and Georges, C.: Modelling observed and future runoff from a glacierized

604 tropical catchment (Cordillera Blanca, Perú), Global and Planetary Change, 59, 1-4, 37-48, 2007.

605 Kaser, G., Ames, A., and Zamora, M.: Glacier fluctuations and climate in the Cordillera Blanca, 606 Peru, Annals of Glaciology, 14, 136-140, 1990.

607 Kaser, G. and Georges, C.: Changes of the equilibrium-line altitude in the tropical Cordillera 608 Blanca, Peru, 1930-50, and their spatial variations, Annals of Glaciology, 24, 344-349, 1997.

609 Kaser, G. and Osmaston, H. A.: Tropical glaciers, Cambridge University Press, Cambridge, 610 United Kingdom, 2002.

611 Lliboutry, L., Morales, B., Schneider, B.: Glaciological problems set by the control of dangerous 612 Lakes in Cordillera Blanca, Peru. III. Study of Moraines and mass balances at Safuna, Journal of 613 Glaciology, 18 (79), 275-290, 1977.

614 Mark, B. G. and Seltzer, G. O.: Tropical glacier meltwater contribution to stream discharge: A 615 case study in the Cordillera Blanca, Peru, Journal of Glaciology, 49 (165), 271-281, 2003.

616 Mark, B. G. and McKenzie, J. M.: Tracing increasing tropical Andean glacier melt with stable 617 isotopes in water, Environmental Science and Technology, 41 (20), 6955-6960, 2007.

618 Mark, B. G., Bury, J., McKenzie, J. M., French, A., and Baraer, M.: Climate change and tropical

619 Andean glacier recession: evaluating hydrologic changes and livelihood vulnerability in the 620 Cordillera Blanca, Peru, Annals of the Association of American Geographers 100, 794-805, 6212010.

622 Mark, B. G., McKenzie, J. M., and Gomez, J.: Hydrochemical evaluation of changing glacier 623 meltwater contribution to stream discharge: Callejon de Huaylas, Peru, Hydrological Sciences 624 Journal, 50, 975-987, 2005.

625 Mateo, E. I., Mark, B. G., Hellström, R. Å., Baraer, M., McKenzie, J. M., Condom, T., Rapre, A. 626 C., Gonzales, G., Gómez, J. Q., Encarnación, R. C. C.: High temporal resolution 627 hydrometeorological data collected in the tropical Cordillera Blanca, Peru (2004-2020), 628 HydroShare, https://doi.org/10.4211/hs.059794371790407abd749576df8fd121, 2021.

629 McNulty, B. A., Farber, D. L., Wallace, G. S., Lopez, R., and Palacios, O.: Role of plate 630 kinematics and plate-slip-vector partitioning in continental magmatic arcs: Evidence from the 631 Cordillera Blanca, Peru, Geology, 26 (9), 827-830, 1998.

632 Petersen, U., Sassarini, L., Plenge, R.,: Glaciar Yanasinga (Central Peru): 24 years of 633 measurements, Journal of Glaciology, 8 (54), 487-489, 1969. 
634 RGI Consortium: Randolph Glacier Inventory - A Dataset of Global Glacier Outlines: Version 635 6.0: Technical Report, Global Land Ice Measurements from Space, Colorado, USA, Digital 636 Media, DOI: https://doi.org/10.7265/N5-RGI-60, 2017.

637 Schauwecker, S., Rohrer, M., Acuna, D., Cochachin, A., Davila, L., Frey, H., Giraldez, C., 638 Gomez, J., Huggel, C., Jacques-Coper, M., Loarte, E., Salzmann, N., and Vuille, M.: Climate 639 trends and glacier retreat in the Cordillera Blanca, Peru, revisited, Global and Planetary Change, 640 119, 85-97, doi:10.1016/j.gloplacha.2014.05.005, 2014.

641 Vuille, M., Carey, M., Huggel, C., Buytaert, W., Rabatel, A., Jacobsen, D., Soruco, A., Villacis, 642 M., Yarleque, C., Elison Timm, O., Condom, T., Salzmann, N., and Sicart, J.-E.: Rapid decline 643 of snow and ice in the tropical Andes - impacts, uncertainties and challenges ahead, Earth644 Science Reviews, 176, 195-213, https://doi.org/10.1016/j.earscirev.2017.09.019, 2018. 